\title{
Has the US-China Trade War Caused Trade Decoupling?
}

Author(s): Jeonghyun Kim, Jinmyon Lee, Bawoo Kim

Source: Journal of International Logistics and Trade 2021; 19(4):211-222

Published by: Jungseok Research Institute of International Logistics and Trade, Inha University

DOI: https://doi.org/10.24006/jilt.2021.19.4.211

Journal of International Logistics and Trade is an official journal published by Jungseok Research Institute of International Logistics and Trade, Inha University, Korea. JILT welcomes manuscripts that advance the practice and science of logistics, trade, and other related fields.

Frequency: Quarterly (March, June, September, December)

Stable URL: https://www.ejilt.org

Jungseok Research Institute of International Logistics and Trade is a specialized academic research institute representing Inha University and Inha Foundation in Korea. The institute aims to become a representative institute in Northeast Asia in the research of logistics and trade.

Stable URL: https://jrieng.inha.ac.kr

(C) Copyright. Jungseok Research Institute of International Logistics and Trade.

This is an Open-Access article distributed under the terms of the Creative Commons Attribution NonCommercial License (http://creativecommons.org/licenses/by-nc/4.0/) which permits unrestricted noncommercial use, distribution, and reproduction in any medium, provided the original work is properly cited 



\title{
Journal of International Logistics and Trade
}

J. Int. Logist. Trade, 2021, Vol. 19, No. 4, 211-222

pISSN : 1738-2122 eISSN : 2508-7592

https://doi.org/10.24006/jilt.2021.19.4.211

https://www.ejilt.org

\section{ARTICLE}

\section{Has the US-China Trade War Caused Trade Decoupling?}

\author{
Jeonghyun Kim, Jinmyon Lee, Bawoo Kim* \\ Korea Institute for Industrial Economics \& Trade, Sejong 30147, Korea
}

$\begin{array}{ll}\text { Received } & \text { September 6, } 2021 \\ \text { Revised } & \text { November 27, } 2021 \\ \text { Accepted } & \text { December 8, } 2021 \\ & \\ & \\ \text { *Corresponding author: Bawoo Kim } \\ \text { Korea Institute for Industrial Economics \& } \\ \text { Trade, Sejong 30147, Korea } \\ \text { Tel: +82-44-287-3921 } \\ \text { E-mail: instrumist@kiet.re.kr }\end{array}$

Received September 6, 2021

Revised November 27, 202

\begin{abstract}
Recently, decoupling between the US and China has emerged as an important issue in global economics. We propose an analytical framework for trade decoupling analysis, borrowing the idea from the production function in non-competitive input-output tables. Using that methodology, we analyze the mobile phone trade network subject to various measures imposed by the US. A scenario analysis is performed to compare the extent of decoupling after a trade war with worst-cases. In bilateral trade, China's share of total US imports fell significantly in 2019 compared to 2017. However, China's indirect exports to the US increased during the same period. A similar pattern is observed in the global trade network visualized via multidimensional scaling (MDS). China's out-degree centrality decreased slightly, while Vietnam's role expanded. Actual figures for 2019 show a decreased out-degree centrality for Chinese final good exports, but a much higher one in the scenarios. Also, China's indirect exports to the US have increased. But China does not appear to play a key role in the network as assumed in the scenario. Throughout the study, intermediate goods were treated homogeneously, and further studies considering the heterogeneity of input-output linkages are needed.
\end{abstract}

Keywords Network, Decoupling, Trade war, International trade

\section{Introduction}

Recently, decoupling between the US and China has emerged as an important issue in global economics. Decoupling refers to the phenomenon by which the economies of two or more countries deviate from a similar or global trend. There are many examples in which the correlation of specific indicators decreases, particularly in finance, where the phenomenon can be seen in stock prices and interest rates. The withdrawal of a specific country from the existing international division of labor can also be seen as decoupling in a broad sense. The US-China decoupling, which is the theme of this study, has been largely in terms as follows.

First, the decoupling of the trade sector is directly attributable to the US-China trade war. In March 2018, the Trump administration imposed additional tariffs on Chinese steel and aluminum, sparking a trade war between the US and China. Since then, from 2018 to the end of 2019, the US and China have imposed four additional tariffs apiece. Bilateral trade decoupling caused by trade disputes is characterized as a market reaction to the policy of imposing additional tariffs.

Second, the decoupling of the global production network is a result of the competition for hegemony. Following the administration of former President Donald Trump, the current Joe Biden administration of the US views China as a hegemonic competitor and is implementing various measures. The hegemony competition leads to decoupling in technology and industry. For example, in July 2018, the US government banned the sale of products from Micron, an American semiconductor company, in China. In May 2019, Huawei and 58 overseas affiliates of China were added to the US Department of Commerce's export control list. These actions by the US initiated a decoupling between the two countries in the fields of technology and the international division of labor. In response to US technology regulations, the Chinese government's policy stance toward global production networks has also changed. In 2018, Secretary General Xi Jinping emphasized self-reliance in core technologies.

The technological and industrial decoupling of the two countries is highly likely to bring about changes in the global production networks that have revolved around the two countries since the 1990s. In other words, in the future international division of labor, production networks centered on the US and China are expected to compete. Recent studies also show signs of decoupling between the US and China. For example, US dependence on China has decreased, as shown by the Reshoring Index of US companies rising to an all-time high in 2019. 
Since the decoupling caused by the trade war is spreading from bilateral trade to competition for hegemony in various sectors, it also should be analyzed from various aspects. Typical decoupling analyses in the financial field are based on time series approaches. However, since it is difficult to secure many data points for trade statistics, it is difficult to apply this methodology. And since a market share analysis is limited to direct transactions between the two countries, it is difficult to examine the decoupling from this point of view.

In consideration of various aspects of this decoupling between the US and China, we specified the following research objectives for this study. First, we propose a comprehensive approach to the study of trade decoupling by using network analysis. There are few empirical analyses of trade decoupling, and most existing studies are based on cross-sectional data. This paper suggests a framework for a trade network decoupling analysis, adopting the idea from the production function of noncompetitive input-output tables and network analysis techniques. Second, using the methodology suggested above, we analyze the mobile phone trade network since smartphones are made with various cutting-edge technologies and subject to various US measures. Finally, we build a scenario in which the trade war intensifies and analyze its effects on the US and China. This allows us to see how much the trade network has changed since the actual trade war compared to the worst-case scenario.

The remainder of the study is structured as follows. Section 2 reviews the literature on previous work on economic decoupling. Chapter 3 describes the data and methodology of this study, especially trade data and network analysis methods. Section 4 reports the main results. Chapter 5 concludes with recommendations for future research.

\section{Literature review}

In an economic sense, decoupling refers to the phenomenon by which the economy of a country or region deviates from trends in neighboring countries or the overall global economy. The opposite phenomenon is called coupling, or synchronization. In general, decoupling and coupling are repeated periodically. Especially, the transition from decoupling to coupling is called recoupling. Based on the above concepts, the decoupling of the US-China trade means that the trade flows between the two countries change in different ways.

Internationally, decoupling studies have focused on macroeconomic flows between countries after the global financial crisis. There is no mainstream methodology for measuring decoupling in existing studies. Various methods have been used, including econometric models, correlation coefficients, and descriptive statistical analysis. How decoupling is determined will inevitably differ by analytical method employed. When using an econometric model, the determination is based on statistical significance and the sign of the estimate. In research using the Granger causality model, coupling or decoupling is determined depending on whether changes occur sequentially in the same direction between specific variables. Table 1 summarizes research on decoupling and coupling.

Kim et al. (2011) showed that economic growth in Asia is related to global economic integration. After the Asian financial crisis of 1997, relations between Asian countries and developed countries improved. Therefore, Kim et al. (2011) argued for the necessity of political cooperation against economic risk, between Asian countries and rest of the world. Fidrmuc et al. (2013) found that economic ties as measured by the co-movement of business indices between China and the OECD countries were strong only in the short run. Also, other countries with a large share of trade with China also do not appear to be closely connected with the OECD. Bekiros (2014) attempted to evaluate the economic decoupling effect of the financial crisis from a

Table 1. Research on global economic decoupling

\begin{tabular}{|c|c|c|c|}
\hline Research & Subject & Key variable & Methodology \\
\hline $\begin{array}{l}\text { Kim et al. } \\
\text { (2011) }\end{array}$ & $\begin{array}{l}\text { Economic growth in Asian countries and developed } \\
\text { countries after the Asian financial crisis }\end{array}$ & GDP growth rate & Panel VAR \\
\hline $\begin{array}{l}\text { Fidrmuc et al. } \\
\qquad(2013)\end{array}$ & $\begin{array}{l}\text { Economic synchronization between China and OECD } \\
\text { countries }\end{array}$ & Business cycles & $\begin{array}{l}\text { Dynamic correlation } \\
\text { analysis }\end{array}$ \\
\hline $\begin{array}{l}\text { Bekiros } \\
(2014)\end{array}$ & $\begin{array}{l}\text { Stock markets in the US, Europe and BRICS countries } \\
\text { before and after the financial crisis }\end{array}$ & Daily stock index & VAR, GARCH \\
\hline $\begin{array}{c}\text { Park } \\
(2018)\end{array}$ & $\begin{array}{l}\text { Macroeconomic indicators of East Asian countries and the } \\
\text { US, Europe and Japan before and after the financial crisis }\end{array}$ & Macroeconomic indicators & VAR \\
\hline $\begin{array}{l}\text { Rajah } \\
(2019)\end{array}$ & $\begin{array}{l}\text { Final goods exports of East Asian countries, the US, and } \\
\text { EU }\end{array}$ & $\begin{array}{l}\text { Intra-East Asian Trade vs. } \\
\text { Trade with the US and EU }\end{array}$ & Descriptive statistics \\
\hline
\end{tabular}


Table 2. Research on trade network analysis

\begin{tabular}{|c|c|c|c|}
\hline Research & Subject & Key variable & Methodology \\
\hline $\begin{array}{l}\text { Kim and Shin } \\
\quad(2002)\end{array}$ & $\begin{array}{l}\text { Trade among } 105 \text { countries from } 1959 \text { to } \\
1995\end{array}$ & $\begin{array}{l}\text { Node centrality, network } \\
\text { density, geodesic distance }\end{array}$ & Network indices analysis \\
\hline Hidalgo et al. (2007) & Product space between 775 product items & $\begin{array}{l}\text { Pair-wise conditional } \\
\text { probability of RCA indices }\end{array}$ & Diffusion process simulation \\
\hline $\begin{array}{l}\text { De Benedictis } \\
\text { and Tajoli (2011) }\end{array}$ & World trade from 1950 to 2000 & $\begin{array}{l}\text { Node indices (closeness, in- } \\
\text { degree, out-degree) }\end{array}$ & $\begin{array}{l}\text { Regression analysis using network } \\
\text { indices as explanatory variable }\end{array}$ \\
\hline Lee et al. (2021) & Decoupling of the US-China trade & Node indices (in-degree, out- & Network indices analysis \\
\hline Pacini et al. (2021) & Plastic waste imports in 2018 & $\begin{array}{l}\text { degree, betweenness centrality, } \\
\text { eigenvector centrality) }\end{array}$ & Network indices analysis \\
\hline
\end{tabular}

financial standpoint. The study found no consistent evidence of global decoupling after the financial crisis, even as global contagion effects have been widely supported. Rajah (2019) analyzed where products made in East Asia were consumed. In the past, the US and EU accounted for the largest share. But now, Asian countries have a larger share. As a result, East Asian countries can be seen as less risky in the context of the larger US-China trade war, relative to the past.

In terms of trade, Park (2018) claimed that a decrease in extra-regional trade dependence of East Asia is not evidence of decoupling with the US or Europe because the correlation between macroeconomic indicators has strengthened. Kim and Shin (2002) argued for existence of the global trade coupling between 1959 and 1995 by analyzing world trade network.

In this study, network analysis techniques are used to analyze trade decoupling. Network analysis is a technique used to identify the global characteristics of given network as well as local characteristics of a specific node. Early research in international trade only used a network (or a graph) to describe trade patterns (Hilgerdt 1943).

A network is a mathematical concept the structure of which is determined by entities that can be referred to as nodes and links connected to one another. A node (or a vertex) is a connection point. Representative examples are countries, industries, and people. A link (or an edge) represents a connection itself, such as a trade relationship, an input structure, or a marriage. Hidalgo et al. (2007), De Benedictis and Tajoli (2011), and many other studies used network analyses to study trade relationships. Table 2 summarizes research on trade using network analysis.

\section{Data and method}

\subsection{Data construction}

There are various types and sources of trade statistics. In this study data from UN Comtrade (the de facto standard) was used (UN Comtrade, 2021). World Customs Organization (hereafter WCO) member countries share a common commodity classification system, the Harmonized System (hereafter HS). Individual countries have original national tariff lines that conform to HS. Since detailed tariff lines vary from country to country, they cannot be used for international comparisons. Thus, all analyses in this research conducted at HS sub-heading level (6-digits level). Year 2020 is intentionally dropped to avoid the bias caused by the Covid-19 global pandemic. In addition, WCO has formally revised the HS system quinquennially since 2002; the last revision was done in 2017. Thus we set the analysis period from 2017 to 2019.

For a focused analysis, trade in mobile phones and parts — which are expected to be affected by the trade war - were selected from more than 5,200 items according to the HS classification. Mobile phones, classified as HS 8,519.12, are a significant single item in global trade and analyzing the trade network of mobile phones is a useful exercise itself. Analyzing the trade network of the parts category, however, may not produce any special insight owing to the sheer variety of products in the category. We used the list in the Mobile Phone HS Guide published by the Korea Customs Service. The list was used to collapse trade data and generate an "intermediate goods" trade network dataset. Note that now we have two different datasets: one for final goods and one for intermediate goods.

Network analysis is technically performed through an adjacency matrix. There are various ways to construct an adjacency matrix. First, for binary network analysis, a threshold-based reduction could be performed to obtain a Boolean matrix (zeroone matrix). Second, actual values or log-transformed values can be used for weighted network analysis. A Boolean matrix could well represent the topological structure of the entire network, depending on the attribute distribution of the links. Especially in social network analysis, each relationship between nodes is dichotomized from the data coding process. In this 
study, actual values were taken for analysis to preserve, relative magnitude of trade links.

Analyzing the two kinds of trade networks as defined above for final goods and intermediate goods enables us to observe the direct trade relationship between countries exporting each good. However, indirect exports involving three countries or more cannot be analyzed. To tackle this problem, we assume the following production function.

$$
y=\min \left(x^{\text {domestic }}, x^{\text {foregin }}\right)
$$

Here, $y$ represents final goods (HS 851912) and $x$ intermediate goods listed in the appendix 1. This specification means both domestic and foreign intermediate goods are needed for the production of a final good and not interchangeable, as in noncompetitive input-output models. Since $x^{\text {domestic }}$ is unobservable in the data, we focus on $x^{\text {foregin }}$. Imported intermediate goods are considered homogenous.

Based on the production function, indirect final goods exports of country A through country B can be estimated considering the contribution of intermediate goods of country A to country B and the final goods exports of country B. That is, country A's contribution to country B's exports of final goods. Embedded exports refer to the value obtained by multiplying country B's export of final goods by country A's share of country B's intermediate goods imports. By applying it to each country's intermediary and final goods trade matrix, each country's exports of final goods via other countries can be obtained, and we designate these exports indirect final goods exports.

Since international input-output tables assume the relationship between industries, each production linkage could be infinitely extended, and those processes can be expressed in a closed form called the Leontief inverse matrix. However, in this study, final goods are limited to mobile phones, and intermediate goods can be viewed as primary (or 1st-tier) intermediate goods. Raw materials and parts for producing these intermediate goods are not considered. This constitutes a limitation in interpreting the production network.

\subsection{Network centrality measures}

We study the degree of connection between the US and China before and after the US-China trade war. Network analysis was performed to determine the degree of connectivity. The following is a brief introduction to the network settings and the centrality measure used in this study.

Let $N=\{1,2, \ldots, \mathrm{n}\}$ be a set of vertices (or nodes). Given $N$, an adjacency matrix A is a real-valued $n \times n$ matrix where $a_{i j}$ represents the relationship between $i$ and $j$. An adjacency matrix is equivalent to the corresponding graph in terms of information. Thus, every element of adjacency matrix should be non-negative to exclude we exclude negative-distance cases. In binary network analysis setting, every element of an adjacency matrix takes 0 or 1 . And a network is undirected if and only if the adjacency matrix is symmetrical. That is, $a_{i j}=a_{j i}$. Otherwise, a network is directed. In our setting, a country is a vertex and each element of an adjacency matrix denotes trade volumes between row and column-sided countries. A network $g$ over $N$ is a subset of a complete graph $G_{N} \equiv\{(i, j) \mid \forall i, j \in N, i \neq j\}$, whose element is an edge (arc or link). In a weighted network analysis setting, we have $g=\left\{(i, j) \mid \forall i, j \in N\right.$, s.t. $\left.i \neq j, a_{i j}>0\right\}$.

Centrality is most widely used concept for measuring a network. A centrality index that corresponds to a vertex is itself meaningful. The distribution of centrality reflects the systemic property of a network. The most straightforward concept of centrality is degree centrality. For binary network analysis, Freeman (1977) defined degree centrality of a vertex by the number of connections the vertex has (formula 1). Since trade has intrinsic direction, degree centrality can be divided into out-degree centrality and in-degree centrality. Out-degree centrality for a node can be obtained with formula 1, and we can get in-degree centrality by simply transposing the adjacency matrix. In a weighted network setting, a country's degree centrality equals its total trade volume (Barrat et al. 2004). Kim and Shin (2002) show that the world became significantly globalized between 1959 and 1996 based on the increase in world average degree centrality.

$$
c_{i}^{\text {degree }}=\frac{1}{n-1} \sum_{i \neq j} a_{i j}
$$

Eigenvector centrality was proposed by Bonacich (1972). Intuitively speaking, the centrality of a vertex is determined by the centrality of its neighbors. In linear algebra fashion, it can be obtained by the eigenvector corresponding to the largest real eigenvalue. This is an equivalent concept to the Gould index of accessibility or the Perron vector. And thanks to Perron- 
Frobenius theorem, it is guaranteed that the Perron vector of an adjacency matrix $A$ exists as we consider non-negative trades. It can be expressed in mathematical terms as below.

$$
c_{i}^{\text {eigenvector }}=\sum_{j \in N} a_{i j} c_{i}^{\text {eigenvector }}
$$

In matrix notation, the formula can be simplified as follows.

$$
\gamma c^{\text {eigenvector }}=\mathrm{A} c^{\text {eigenvector }}
$$

Closeness and betweenness centrality measures are also frequently used in the literature. But, since we divide a country into two in its production stage, those metrics that are sensitive to the pair-wise geodesic distances become less meaningful.

\section{The US-China decoupling in the mobile phone trade}

The US has the largest consumer market, with a GDP of 21 trillion USD (World Bank, 2021) which accounts over 15 percent of global GDP. China has grown into the world's factory, thanks to abundant labor and natural resources. Foreign direct investment, which increased after China joined the WTO, accelerated the industrialization of the country. However, soaring labor costs and reinforced intellectual property protection policies are hindering the effectiveness of a growth strategy that relies on trade.

Mobile phones typify how China functions as a production base and the US as the largest market. Also, as disputes over communications technology and intellectual property rights continue between the two, we expect trade in phones to clearly illustrate the aftermath of the trade war than any other product. Thus, in this section, we investigate the US-China decoupling in mobile phone trade networks.

The key to the US-China decoupling analysis is determining whether the US functions as an important source of demand for China and whether China functions as a US production base. China has served as a production base for global brands, and the US has imported mobile phone products from China. The processing trade, in which intermediate parts are imported from abroad, processed, assembled and re-exported, has been the source of technological development in China (Kim 2017).

If the US-China decoupling has occurred, the attractiveness of the US as a Chinese export market would have declined, and vice versa. It is very difficult to predict the effect intuitively. First, there are not enough manufacturing plants to replace China. For instance, the iPhone has been manufactured by Foxconn factories in China for a long time. Although Samsung moved its manufacturing facilities from China to Vietnam, China remains an irreplaceable production hub for many global brands, and a short-term substitution is almost impossible. On the other hand, the US has implemented a number of regulatory measures aimed at China. Cooperation with Chinese manufacturers, parts made in China, and final assembly in China are all subject to regulation. Therefore, a bilateral analysis of mobile phone trade between the two countries is not sufficient to gauge the USChina decoupling.

To tackle this problem, in this section we perform the following analyses. First, we compare bilateral trade between the two countries in 2017 and 2019 by product category: final goods, intermediate goods, and indirect final goods. Second, we analyze topological changes to the global trade network and major nodes (countries). Finally, we present a scenario analysis of an intensified US-China trade war.

\subsection{Change in bilateral trade}

The pattern of decoupling between the US and China can be identified in a crude manner through an analysis of bilateral trade in final goods. Indirect exports via a third country can be calculated using the equation presented above.

After the trade dispute, China's direct exports to the US and its share of exports both decreased significantly. As shown in Table 4, China's direct exports of mobile phones to the US fell, from 45 billion USD in 2017 to 40 billion USD in 2019. During the same period, China's share of direct mobile phone exports fell sharply, from 80 to 72 percent. Imports from the world also decreased by 1.6 billion USD, from 56 billion to 55 billion USD (Table 3). The decline in imports from China amounted to 5.3 billion USD.

In the case of indirect exports, the proportion of Chinese exports is relatively low, since direct exports from China are excluded from the calculation. But the size and proportion of such exports appear to be gradually increasing during the same 
Table 3. Imports of mobile phones by country

\begin{tabular}{|c|c|c|c|c|c|}
\hline & \multirow[b]{2}{*}{ World } & \multicolumn{2}{|c|}{ China } & \multicolumn{2}{|c|}{ US } \\
\hline & & $\begin{array}{c}\text { Value } \\
\text { (Billion USD) }\end{array}$ & $\begin{array}{l}\text { Share of global } \\
\text { imports }(\%)\end{array}$ & $\begin{array}{c}\text { Value } \\
\text { (Billion USD) }\end{array}$ & $\begin{array}{l}\text { Share of global } \\
\text { imports }(\%)\end{array}$ \\
\hline 2017 & 235.8 & 4.3 & 1.8 & 56.2 & 23.8 \\
\hline 2018 & 236.0 & 4.9 & 2.1 & 53.8 & 22.8 \\
\hline 2019 & 226.6 & 5.2 & 2.3 & 54.6 & 24.1 \\
\hline
\end{tabular}

Table 4. Decomposition of mobile phone trade between the US and China

\begin{tabular}{|c|c|c|c|c|c|c|c|c|}
\hline \multirow{2}{*}{ Year } & \multicolumn{2}{|c|}{$\begin{array}{l}\text { China } \rightarrow \text { US } \\
\quad(\text { direct })\end{array}$} & \multicolumn{2}{|c|}{$\begin{array}{l}\text { China } \rightarrow \text { US } \\
\quad \text { (indirect) }\end{array}$} & \multicolumn{2}{|c|}{$\begin{array}{l}\text { US } \rightarrow \text { China } \\
\quad(\text { direct })\end{array}$} & \multicolumn{2}{|c|}{$\begin{array}{l}\text { US } \rightarrow \text { China } \\
\text { (indirect) }\end{array}$} \\
\hline & $\begin{array}{c}\text { Value } \\
\text { (Million USD) }\end{array}$ & Share $(\%)$ & $\begin{array}{c}\text { Value } \\
\text { (Million USD) }\end{array}$ & Share $(\%)$ & $\begin{array}{c}\text { Value } \\
\text { (Million USD) }\end{array}$ & Share $(\%)$ & $\begin{array}{c}\text { Value } \\
\text { (Million USD) }\end{array}$ & Share $(\%)$ \\
\hline 2017 & $45,064.4$ & $80.2 \%$ & $3,995.1$ & $7.1 \%$ & $2,251.9$ & $52.4 \%$ & 183.7 & $4.3 \%$ \\
\hline 2018 & $44,500.5$ & $82.7 \%$ & $2,920.7$ & $5.4 \%$ & $3,027.4$ & $61.9 \%$ & 162.4 & $3.3 \%$ \\
\hline 2019 & $39,736.6$ & $72.8 \%$ & $4,689.4$ & $8.6 \%$ & $3,164.4$ & $60.3 \%$ & 188.1 & $3.6 \%$ \\
\hline
\end{tabular}

period, jumping from 3.9 billion USD in 2017 to 4.6 billion in 2019 . This implies the role of the US as a consumer market for China is shrinking. The rising share of other countries' exports to the US market also supports this observation. China is increasing its indirect exports to the US by exporting intermediate goods to third countries. China's overall import market size is not that large due to its high competitiveness, but the US accounts for more than half of imports.

\subsection{Changes in trade networks}

The above analysis illuminates the two countries' decoupling in bilateral trade. Decoupling in the global trade network can be seen in the similarity of linkages. Figures 1 and 2 represent world trade networks in 2017 and 2019, reflecting the similarities of each country using MDS.

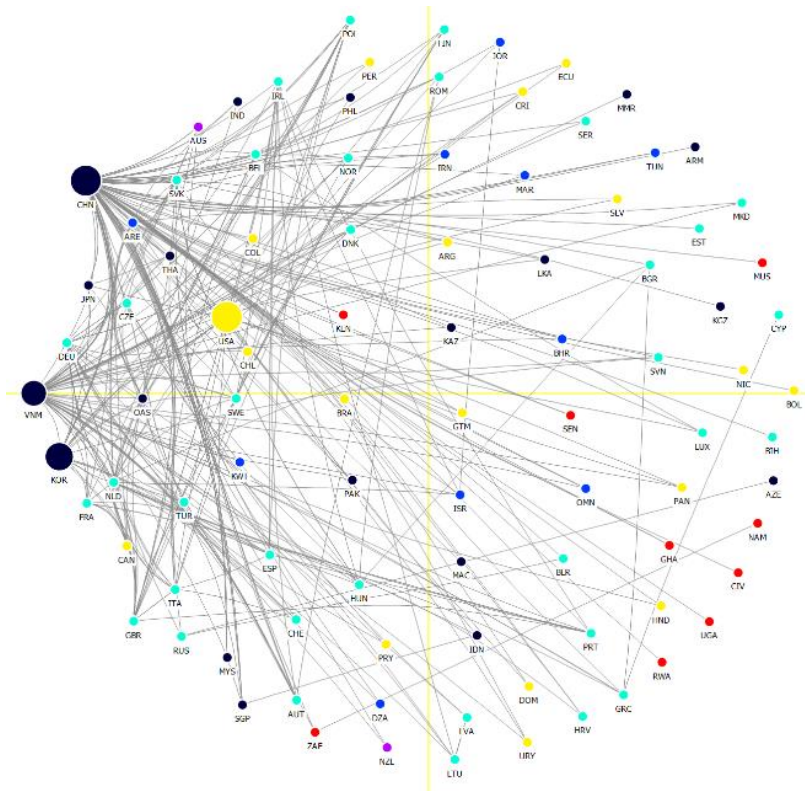

Figure 1. World trade network of mobile phones in 2017, based on MDS. MDS, multidimensional scaling. 


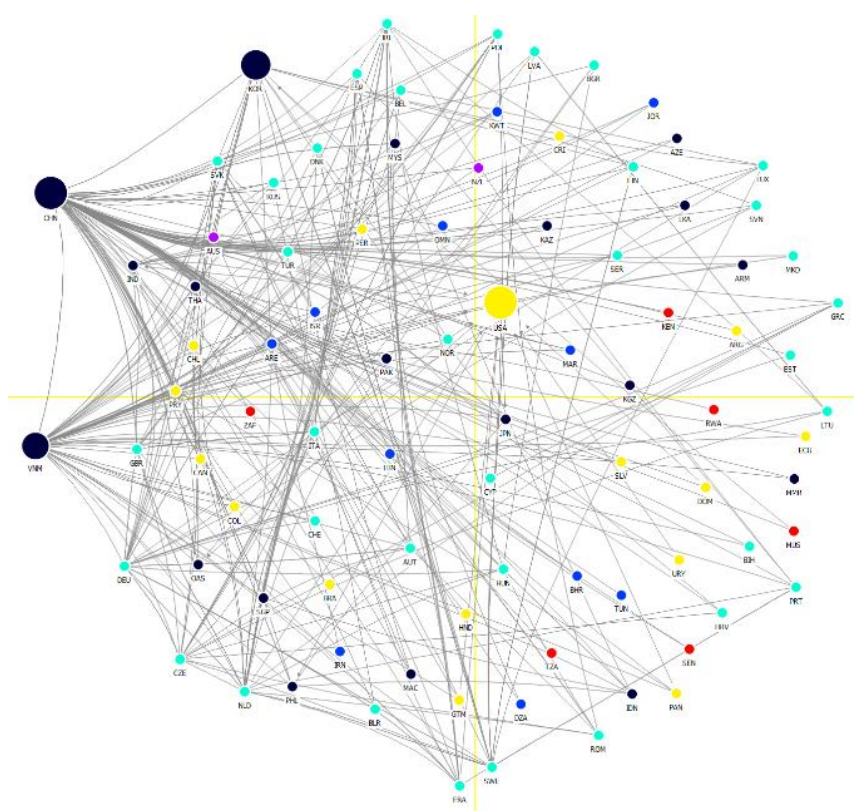

Figure 2. World trade network of mobile phones in 2019, based on MDS. MDS, multidimensional scaling.
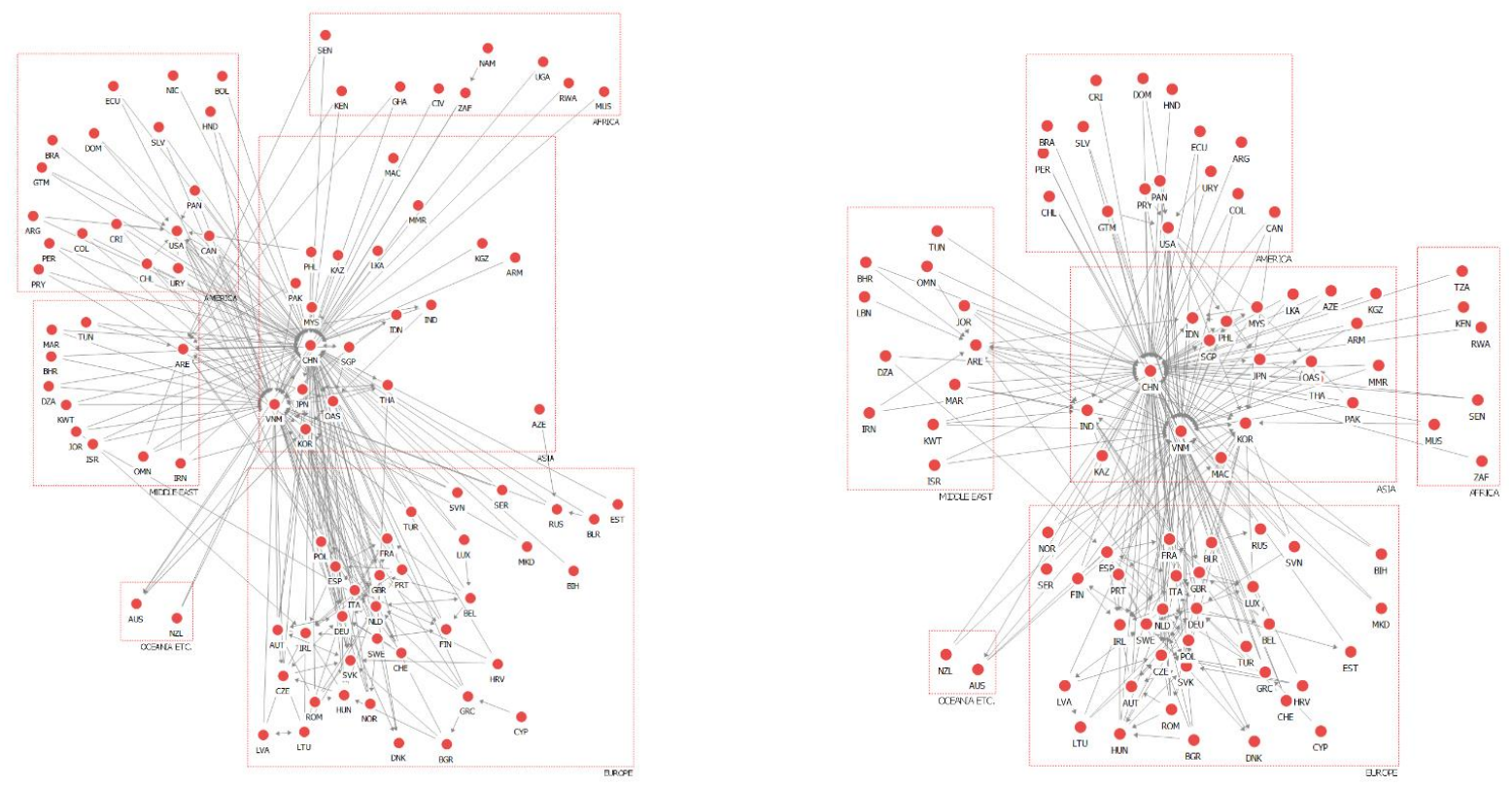

Figure 3. World trade network of mobile phones, based on Eades clustering in 2017 (left) and 2019 (right).

The color of the node distinguishes the continent in which each country is located. To enhance visibility, China, the US, and Korea have been slightly enlarged. In 2017, manufacturing powerhouses including China, Japan, Germany, Vietnam, and South Korea were found to be relatively close. The US, a key source of demand, is located close to major suppliers. But in 2019, the US has moved a bit further away from major suppliers, reflecting decreased similarities in its trade network. Interestingly, Japan has moved closer to the US. Japan's dependence on exports to China fell from 77 percent in 2017 to 59 percent in 2019 , while its dependence on exports to the US increased over the same period, from 14 to 28 percent.

Also, Figure 3 shows that a significant change occurred in the overall network structure between the two time points. The 
Table 5. Changes in centrality indices of major countries by product type

\begin{tabular}{|c|c|c|c|c|c|c|c|}
\hline \multirow[b]{2}{*}{ Country } & \multirow[b]{2}{*}{ Year } & \multicolumn{2}{|c|}{ Final goods (direct) } & \multicolumn{2}{|c|}{ Final goods (indirect) } & \multicolumn{2}{|c|}{ Intermediate goods } \\
\hline & & $\begin{array}{l}\text { Eigenvector } \\
\text { centrality }\end{array}$ & $\begin{array}{c}\text { Out-degree } \\
\text { centrality }\end{array}$ & $\begin{array}{c}\text { Eigenvector } \\
\text { centrality }\end{array}$ & $\begin{array}{c}\text { Out-degree } \\
\text { centrality }\end{array}$ & $\begin{array}{l}\text { Eigenvector } \\
\text { centrality }\end{array}$ & $\begin{array}{l}\text { Out-degree } \\
\text { centrality }\end{array}$ \\
\hline \multirow[t]{3}{*}{ China } & 2017 & 0.7001 & 0.6586 & 0.0349 & 0.0906 & 0.5767 & 0.1781 \\
\hline & 2018 & 0.7031 & 0.6644 & 0.0289 & 0.0755 & 0.5380 & 0.1627 \\
\hline & 2019 & 0.7028 & 0.6246 & 0.0291 & 0.0880 & 0.5351 & 0.1685 \\
\hline \multirow[t]{3}{*}{ Korea } & 2017 & 0.1226 & 0.0363 & 0.4373 & 0.2323 & 0.3619 & 0.1417 \\
\hline & 2018 & 0.0947 & 0.0277 & 0.4505 & 0.2338 & 0.3643 & 0.1505 \\
\hline & 2019 & 0.0935 & 0.0260 & 0.4230 & 0.1987 & 0.3804 & 0.1257 \\
\hline \multirow[t]{3}{*}{ USA } & 2017 & 0.6447 & 0.0177 & 0.6976 & 0.0484 & 0.3539 & 0.0565 \\
\hline & 2018 & 0.6320 & 0.0171 & 0.6916 & 0.0482 & 0.3319 & 0.0549 \\
\hline & 2019 & 0.6288 & 0.0237 & 0.7012 & 0.0539 & 0.2911 & 0.0570 \\
\hline \multirow[t]{3}{*}{ Vietnam } & 2017 & 0.0229 & 0.1565 & 0.0213 & 0.0463 & 0.2707 & 0.0390 \\
\hline & 2018 & 0.0225 & 0.1546 & 0.0222 & 0.0548 & 0.2607 & 0.0432 \\
\hline & 2019 & 0.0260 & 0.1774 & 0.0235 & 0.0589 & 0.2992 & 0.0507 \\
\hline
\end{tabular}

change in the network status of major nodes can be summarized as weakening of China's centrality and a strengthening of Vietnam's centrality (Table 5).

Specifically, China's out-degree centrality of final goods direct export was around 0.66 in 2017 and 2018 but had dropped to 0.62 in 2019. No significant change was detected in the eigenvector centrality. Out-degree centrality of indirect exports did not change significantly, while eigenvector centrality decreased slightly, from 0.035 to 0.029 . In the case of intermediate goods exports, out-degree centrality decreased from 0.178 to 0.168 , and eigenvector centrality also decreased, from 0.577 to 0.535 .

In case of the US, the eigenvector centrality of final goods direct exports fell from 0.64 in 2017 to 0.63 in 2019, reflecting decreased bilateral trade. The out-degree centrality slightly increased, from 0.018 to 0.024 . Notably, the centrality of the US in indirect exports increased slightly in 2019. This proves that the US still plays an important role in the trade network, despite decreased trade volumes with China.

Vietnam showed an increased centrality index in all categories during the same period. Out-degree centrality rapidly increased. Eigenvector centrality is small compared to other countries, because the export structure of final goods in Vietnam is biased toward specific countries, and it does not yet occupy a central position in the network. In the case of intermediate goods trade, eigenvector centrality is high due to intensive trade with East Asian countries that play a relatively important role in the network.

The results could be interpreted as follows. China's exports to the US are of the greatest importance in the mobile phone trade, having accounted for 19.1 percent of the entire global trade in mobile phones in 2017. The mobile phone network must be understood with the flow at the center. The recent decline in China's out-degree centrality in direct exports is because the size and share of exports to the US have fallen sharply. The change in eigenvector centrality in the US can also be understood along a similar line. Since China is the most important exporter of mobile phones not only to the US but also to the world, the stronger the connection with China, the higher the Eigenvector centrality. The link between the two countries weakened as the US reduced its share of imports from China. At the same time, China's total exports also decreased, leading to a decline in the US' eigenvector centrality. On the other hand, China's eigenvector centrality remained unchanged, as there was no significant difference in global market share except for a decrease in exports to the US.

\subsection{Scenario analysis}

In the previous section, we observed a significant change in trade networks following the commencement of the trade war. However, there remains the possibility of escalation of the war. For instance, the items subject to Section 301 Tariff Action of the US have been partially suspended through public hearing processes. Also, President Joe Biden issued Executive Order 14017, titled "America's Supply Chains." It could in fact signal the beginning of a new regulatory policy stance. Therefore, a scenario analysis of the trade war is warranted. In the following analysis, based on the 2017 trade network, we analyze the network node centrality of the two countries in three cumulative scenarios that assume stronger US regulations targeting China. 
Table 6. Changes in centrality indices of major countries by product types

\begin{tabular}{|c|c|c|c|c|c|c|c|}
\hline \multirow[b]{2}{*}{ Country } & \multirow[b]{2}{*}{ Scenario } & \multicolumn{2}{|c|}{ Final goods (direct) } & \multicolumn{2}{|c|}{ Final goods (indirect) } & \multicolumn{2}{|c|}{ Intermediate goods } \\
\hline & & $\begin{array}{l}\text { Eigenvector } \\
\text { centrality }\end{array}$ & $\begin{array}{l}\text { Out-degree } \\
\text { centrality }\end{array}$ & $\begin{array}{l}\text { Eigenvector } \\
\text { centrality }\end{array}$ & $\begin{array}{l}\text { Out-degree } \\
\text { centrality }\end{array}$ & $\begin{array}{l}\text { Eigenvector } \\
\text { centrality }\end{array}$ & $\begin{array}{c}\text { Out-degree } \\
\text { centrality }\end{array}$ \\
\hline \multirow[t]{4}{*}{ China } & Base & 0.7001 & 0.6586 & 0.0349 & 0.0906 & 0.5767 & 0.1781 \\
\hline & Sce1 & 0.7040 & 0.5779 & 0.3420 & 0.1125 & 0.5767 & 0.1781 \\
\hline & Sce2 & 0.7040 & 0.5779 & 0.3420 & 0.1125 & 0.5767 & 0.2011 \\
\hline & Sce3 & 0.7049 & 0.5903 & 0.3994 & 0.1141 & 0.5767 & 0.2011 \\
\hline \multirow[t]{4}{*}{ KOR } & Base & 0.1226 & 0.0363 & 0.4373 & 0.2323 & 0.3619 & 0.1417 \\
\hline & Sce1 & 0.1393 & 0.0449 & 0.5084 & 0.2316 & 0.3619 & 0.1417 \\
\hline & Sce2 & 0.1393 & 0.0449 & 0.5084 & 0.2316 & 0.3620 & 0.1297 \\
\hline & Sce3 & 0.1323 & 0.0355 & 0.4919 & 0.2306 & 0.3620 & 0.1297 \\
\hline \multirow[t]{4}{*}{ USA } & Base & 0.6447 & 0.0177 & 0.6976 & 0.0484 & 0.3539 & 0.0565 \\
\hline & Sce1 & 0.0459 & 0.0219 & 0.3336 & 0.0498 & 0.3539 & 0.0565 \\
\hline & Sce2 & 0.0459 & 0.0219 & 0.3336 & 0.0498 & 0.3539 & 0.0583 \\
\hline & Sce3 & 0.0293 & 0.0224 & 0.2113 & 0.0490 & 0.3539 & 0.0583 \\
\hline \multirow[t]{4}{*}{ Vietnam } & Base & 0.0229 & 0.1565 & 0.0213 & 0.0463 & 0.2707 & 0.0390 \\
\hline & Sce1 & 0.0507 & 0.1935 & 0.0776 & 0.0443 & 0.2707 & 0.0390 \\
\hline & Sce2 & 0.0507 & 0.1935 & 0.0776 & 0.0443 & 0.2708 & 0.0370 \\
\hline & Sce3 & 0.0506 & 0.1884 & 0.0807 & 0.0441 & 0.2708 & 0.0370 \\
\hline
\end{tabular}

First, Scenario 1 assumes that the US blocks final goods (mobile phone) imports from China. Flows going in the opposite direction (that is, final goods mobile phone exports from the US to China) are not considered owing to the small scale of such trade. Scenario 2, in relation to Scenario 1, assumes a decline in Chinese imports of intermediate goods in the mobile phone industry. Third countries' exports of intermediate goods to China will decrease as Chinese exports to the US decrease. As discussed above, it is assumed that a decrease in China's imports of intermediate goods is proportional to a decrease in imports from the US, following the production function of the non-competitive input-output table. Scenario 3 assumes that the US also regulates imports from third countries. Specifically, it is assumed that the import of final goods composed of intermediate goods from China is regulated. As in Scenario 2, it is assumed that each country's decline in mobile phone exports to the US is proportional to the proportion of imports of intermediate goods to China. The results are shown in Table 6.

The scenarios assume strong import regulations that are just theoretically possible in the long run. However, comparing the scenario analysis results with the current situation carries implications since it allows us to gauge the degree of decoupling revealed. To review, Scenarios 1 and 3 cause a change in the final goods trade structure, and Scenario 2 causes a change in the intermediate goods trade structure. It should be noted that the impact is limited to the countries with trade relations to the US and China.

In Scenario 1, China's out-degree centrality decreased in the final goods trade network. In the indirect trade network, it increased slightly. Out-degree centrality refers to the degree of centrality of an individual node compared to its connections to all nodes. Thus, this change can be interpreted as a result of a decrease China's global share of the final goods market. Since the property of eigenvector centrality is not significantly affected by change in a few links, eigenvector centrality is for the most part maintained. However, in the case of indirect trade networks, eigenvector centrality increased significantly, from 0.0349 to 0.3420. As we assume in this scenario that US imports from China cease altogether, the out-degree centrality of other countries rose slightly. However, as China is the largest import partner of the US, the eigenvector centrality of the US greatly decreased.

In Scenario 2, the out-degree centrality of Japan, Korea and Taiwan - which mainly supply intermediate goods to China decreased. Since the export of intermediate goods to China was adjusted proportionally, the extent of the change was not large. Considering the heterogeneity of intermediate goods, a more realistic result can be obtained if the impact of demand shock is assumed differently depending on the bundle of intermediate goods supplied to China. However, this is beyond the scope of this study.

In Scenario 3, China's out-degree centrality was slightly higher than in the previous scenario. This is because in this scenario, other countries' exports to the US also decreased and global average connectivity decreased. China's out-degree centrality was 0.578 in Scenarios 1 and 2, but 0.59 in Scenario 3. Korea and Taiwan changed from 0.045 to 0.036 and from 0.009 to 0.008 , 
respectively.

\section{Conclusion}

The decoupling of US-China trade carries implications of enormous significance for the Korean economy, since Korea is an active participant in global value chain activities with both countries. As of 2019, China and the US accounted for 23.3 and 12.9 percent of Korean trade, respectively, taking the first and second positions. If the trade dispute between the two countries is protracted and trade decoupling intensifies, the impact on Korean trade will be significant.

This study analyzed the decoupling of mobile phone trade between the US and China. First, in bilateral trade, China's share of total US imports fell significantly in 2019 compared to 2017. However, China's indirect exports to the US increased during the same period. A visualized global trade network built using MDS also showed decoupling between China and the United States, confirming that the trade structures of the two countries grew less similar as bilateral trade fell. When it comes to role of individual nodes in the network, China's out-degree centrality, which reflects its importance as an exporting country, decreased slightly. Meanwhile, in Vietnam, all centrality indices increased during the same period, pointing to Vietnam's enhanced role in the network along concomitant with an increase in trade volume.

Scenarios in which the US restricts imports from China were also analyzed. We found that when the US restricts imports of final goods from China, China's out-degree centrality and the US' eigenvector centrality decreased. A scenario in which the US also limited imports of intermediate goods, we found that the out-degree centrality of Korea and Vietnam would become slightly smaller. Actual figures for 2019 show that China has seen a decrease in out-degree centrality. However, when compared to the figures in the scenario, it turned out to be much higher. In the case of indirect exports, contrary to the scenario, both out-degree centrality and the eigenvector centrality decreased in real figures. It is worth noting that both the total volume and proportion of China's indirect exports to the US increased in bilateral trade. In other words, although China's indirect exports to the US have increased, China does not appear to play a key role in the network as assumed in the scenario.

Recently published studies of strategic dependence offer hints about the future of the US-China trade decoupling. According to the executive order, the US investigates the supply chain of 4 goods that have a large trade deficit and are highly dependent on imports from China. Rogers et al. (2020) and EU (2021) evaluated the strategic dependence of all imported items. Three strategic dependence indicators were established: trade balance, dependence on China, and China's influence in the world market. These studies suggest that advanced countries perceive high dependence on China as a systematic risk. Kim et al. (2021) pointed out that the US dependence on Chinese goods was mainly formed by comparative advantage rather than sliced GVCs. Kim et al. (2021) called a "dependent product" when there is a global trade deficit and imports from China account for more than $50 \%$ of total imports. More than one-fifth of imports of Korea and of the US come from China. But the US has only 575 dependent products while Korea has 1,088 products. It also turns out that a significant portion of the products are consumer goods. The rising alertness of advanced countries to China suggests the possibility of radical decoupling. However, the current trade structure between the US and China may be maintained as there are relatively few dependent products.

There are two limitations in this study. First, intermediate goods were treated homogeneously. To be more precise, the inputs of each intermediate good are applied to specific final goods heterogeneously. Also, the substitution relationship between countries is ignored due to a paucity of data. There may be a diversification strategy of China's final goods exports in response to reinforced regulations in the US. In addition, intermediate goods suppliers in third countries could seek alternative production strategies that find detours around new regulatory policies.

Second, this study analyzed only a snapshot of the mobile phone import market, due to limitations in information access. However, in reality, not all finished handset products use the global supply chain in equal proportion. Therefore, the analytical results on indirect exports need to be understood in a limited way. Another limitation is that the global mobile phone market is dominated by a small number of major brands. The scenario analysis did not consider the heterogeneous decision-making characteristics of oligopolistic suppliers. Therefore, the results may differ from expectations when specific shocks are applied, as in the scenarios. In addition, the study did not take into account the long-term impact of new manufacturers entering the market. Just as Chinese mobile phone manufacturers have grown on the basis of the country's ICT industry, if Vietnamese mobile phone manufacturers enter the market, a different network can be formed.

In recent years, trade policies tend to be precisely targeted for specific product groups. Identifying products at risk and defining relevant intermediates is critical to predict global decoupling patterns. This paper presents a methodology for estimating ex-post and ex-ante effects of trade policy between countries. Policy design that incorporates this method will generate policies better equipped to cope with a complex international trade environment. 


\section{References}

Barrat, A., Barthélemy, M., Pastor-Satorras, R., Vespignani, A., 2004. The architecture of complex weighted networks. Proceedings of the National Academy of Sciences of the United States of America 101, 3747-3752.

Bekiros, S. D., 2014. Contagion, decoupling and the spillover effects of the US financial crisis: Evidence from the BRIC markets. International Review of Financial Analysis 33, 58-69.

Bonacich, P., 1972. Factoring and weighting approaches to status scores and clique identification. Journal of Mathematical Sociology 2, 113-120.

De Benedictis, L., Tajoli, L., 2011. The world trade network. The World Economy 34, 1417-1454.

European Commission, 2021. Strategic dependencies and capacities. Staff Working Paper 352.

Fidrmuc, J., Korhonen, I., Bátorová, I., 2013. China in the world economy: Dynamic correlation analysis of business cycles. CESifo Economic Studies 59, 392-411.

Freeman, L. C., 1977. A set of measures of centrality based on betweenness. Sociometry 40, 35-41.

Hidalgo, C. A., Klinger, B., Barabási, A. L., Hausmann, R., 2007. The product space conditions the development of nations. Science 317, 482-487.

Hilgerdt, F., 1943, The case for multilateral trade. The American Economic Review 33, 393-407.

Kim, B., 2017. What has China learned from processing trade? Journal of Economic Structures 6, 32.

Kim, B., Kim, Y., Kim, K., 2021. Supply Chain Vulnerability and Impact Path Analysis of Korean Industries. Korea Institute for Industrial Economics and Trade, Sejong, Korea (In Korean).

Kim, S., Lee, J. W., Park, C. Y., 2011. Emerging Asia: Decoupling or recoupling. The World Economy 34, 23-53.

Kim, S., Shin, E. H., 2002. A longitudinal analysis of globalization and regionalization in international trade: A social network approach. Social Forces 81, 445-468.

Lee. J., Kim. B., Kim. J., Lee, J., Kim. H., 2021. Impact of US-China Trade Decoupling on Global Trade Network and Implications for Korea. Korea Institute for Industrial Economics and Trade, Sejong, Korea (In Korean).

Pacini, H., Shi, G., Shi, G., Sanches-Pereira, A., da Silva Filho, A. C., 2021. Network analysis of international trade in plastic scrap. Sustainable Production and Consumption 27, 203-216.

Park, C. Y., 2018. Decoupling Asia revisited, In: Armstrong, A., Westland, T. (Eds), Asian Economic Integration in an Era of Global Uncertainty. Australian National University, Canberra, Australia.

Rajah, R., 2019. East Asia's decoupling. Lowy Institute. Available at: https://www.lowyinstitute.org/publications/east-asia-sdecoupling

Rogers, J., Foxall, A., Henderson, M., Armstrong, S., 2020. Breaking the China Supply Chain: How the 'Five Eyes' can Decouple from Strategic Dependency. Henry Jackson Society, London, UK.

United Nations. 2021. UN Comtrade. Available at: http://comtrade.un.org

USITC. 2021. USITC dataweb. Available at: https://dataweb.usitc.gov

World Bank. 2021. World Bank Open Data. Available at: https://data.worldbank.org/ 
Appendix 1. HS code list of mobile phone parts

\begin{tabular}{|c|c|}
\hline HS code & Description \\
\hline 3926.90 & ARTICLES OF PLASTICS, NESOI \\
\hline 7326.90 & ARTICLES OF IRON OR STEEL, NESOI \\
\hline 7616.99 & ARTICLES OF ALUMINUM, N.E.S.O.I. \\
\hline 8471.60 & $\begin{array}{l}\text { AUTOMATIC DATA PROCESSING INPUT OR OUTPUT UNITS, WHETHER OR NOT CONTAINING } \\
\text { STORAGE UNITS IN THE SAME HOUSING, N.E.S.O.I. }\end{array}$ \\
\hline 8479.89 & MACHINES AND MECHANICAL APPLIANCES HAVING INDIVIDUAL FUNCTIONS, NESOI \\
\hline 8503.00 & PARTS OF ELECTRIC MOTORS, GENERATORS, GENERATING SETS AND ROTAARY CONVERTERS \\
\hline 8504.40 & ELECTRICAL STATIC CONVERTERS; POWER SUPPLIES FOR ADP MACHINES OR UNITS OF 8471 \\
\hline 8504.50 & ELECTRICAL INDUCTORS NESOI \\
\hline 8517.12 & TELEPHONES FOR CELLULAR NETWORKS OR FOR OTHER WIRELESS NETWORKS \\
\hline 8517.62 & $\begin{array}{l}\text { MACHINES FOR THE RECEPTION, CONVERSION AND TRANSMISSION OR REGENERATION OF VOICE, } \\
\text { IMAGES OR OTHER DATA, INCLUDING SWITCHING AND ROUTING APPARATUS }\end{array}$ \\
\hline 8517.70 & $\begin{array}{l}\text { PARTS OF TELEPHONE SETS AND OTHER APPARATUS FOR THE TRANSMISSION OR RECEPTION OF } \\
\text { VOICE, IMAGES OR OTHER DATA }\end{array}$ \\
\hline 8525.80 & TELEVISION CAMERAS, DIGITAL CAMERAS AND VIDEO CAMERA RECORDERS \\
\hline 8529.90 & $\begin{array}{l}\text { PARTS (EXCEPT ANTENNAS AND REFLECTORS) FOR USE WITH RADIO TRANSMISSION, RADAR, } \\
\text { RADIO NAVIGATIONAL AID, RECEPTION AND TELEVISION APPARATUS, NESOI }\end{array}$ \\
\hline 8532.24 & FIXED CAPACITORS NESOI, MULTILAYER CERAMIC DIELECTRIC \\
\hline 8534.00 & PRINTED CIRCUITS \\
\hline 8536.50 & ELECTRICAL SWITCHES FOR A VOLTAGE NOT EXCEEDING 1,000 V, NESOI \\
\hline 8536.69 & ELECTRICAL PLUGS AND SOCKETS FOR A VOLTAGE NOT EXCEEDING 1,000 V \\
\hline 8536.90 & $\begin{array}{l}\text { ELECTRICAL APPARATUS FOR SWITCHING, PROTECTING OR MAKING CONNECTIONS TO OR IN } \\
\text { ELECTRICAL CIRCUITS, FOR A VOLTAGE NOT EXCEEDING 1,000 V, NESOI }\end{array}$ \\
\hline 8538.90 & $\begin{array}{l}\text { PARTS FOR ELECTRICAL APPARATUS FOR ELECTRICAL CIRCUITS, BOARDS, PANELS ETC. FOR } \\
\text { ELECTRIC CONTROL OR DISTRIBUTION OF ELECTRICITY, NESOI }\end{array}$ \\
\hline 8541.10 & DIODES, OTHER THAN PHOTOSENSITIVE OR LIGHT-EMITTING DIODES \\
\hline 8542.31 & PROCESSORS AND CONTROLLERS, ELECTRONIC INTEGRATED CIRCUITS \\
\hline 8542.33 & AMPLIFIERS, ELECTRONIC INTEGRATED CIRCUITS \\
\hline 8543.70 & ELECTRICAL MACHINES AND APPARATUS, HAVING INDIVIDUAL FUNCTIONS, NESOI \\
\hline 8544.42 & $\begin{array}{l}\text { ELECTRIC CONDUCTORS, FOR A VOLTAGE NOT EXCEEDING } 1000 \text { V, FITTED WITH CONNECTORS, } \\
\text { NESOI }\end{array}$ \\
\hline 9013.80 & OPTICAL DEVICES, APPLIANCES AND INSTRUMENTS, NESOI \\
\hline 9031.80 & MEASURING OR CHECKING INSTRUMENTS, APPLIANCES AND MACHINES, NESOI \\
\hline
\end{tabular}

Source: Extracted from Korea Customs, USITC (HS description) (USITC, 2021).

HS, Harmonized System. 